\title{
EXPERIENŢA NOASTRĂ ÎN TRATAMENTUL INFECŢIILOR ULCERELOR VENOASE
}

\section{Cristina-Nicoleta Cozma ${ }^{1}$, Laura Răducu ${ }^{1,2}$, Andra Elena Balcangiu-Stroescu ${ }^{3}$, Daniela Gabriela Bădiță ${ }^{3}$, Cristian Radu Jecan ${ }^{1,2}$}

${ }^{1}$ Secţia de Chirurgie plastică şi Microchirurgie Reconstructivă, Spitalul Clinic de Urgență „Prof. Dr. Agrippa Ionescu“, Bucureşti, România

${ }^{2}$ Departamentul de Chirurgie plastică şi Microchirurgie Reconstructivă,

Universitatea de Medicină şi Farmacie „, Carol Davila“, Bucureşti, România

${ }^{3}$ Facultatea de Medicină Dentară, Universitatea de Medicină şi Farmacie ,, Carol Davila“, Bucureşti, România

\begin{abstract}
REZUMAT
Obiective. Plăgile cronice au o perioadă îndelungată de vindecare, care este influenţată de numeroşi factori, printre care şi infecţiile. Ulcerele venoase reprezintă $80 \%$ din ulceraţiile de la nivelul membrului inferior, având un impact major asupra calităţii vieţii pacientului.

Scopul acestui studiu a fost de a evalua prezenţa bacteriilor şi de a institui un tratament corespunzător în ulcerele venoase.

Material şi metodă. Studiul a înrolat zece pacienţi cu ulcere venoase cronice prezenţi în secţia de Chirurgie plastică a Spitalului Clinic de Urgenţă „Prof. Dr. Agrippa Ionescu“ pe o perioadă de şase luni. Am evaluat cultura plăgilor şi am instituit un tratament corespunzător fiecărui caz în funcţie de antibiogramă.

Rezultate. Ulcerele venoase ale membrului inferior au avut o evoluţie favorabilă după administrarea tratamentului antibiotic şi eliminarea infecţiei. S-a realizat, de asemenea, şi debridarea chirurgicală şi acoperirea plăgii cu o grefă de piele.

Concluzii. Ulcerele venoase pot evolua pe o perioadă îndelungată (săptămâni sau chiar ani), fiind, de asemenea, asociate cu complicaţii severe precum celulită sau transformare malignă. Unul dintre principalii factori care împiedică vindecarea este infecţia, debridarea chirurgicală asociată cu administrarea sistemică de antibiotice având un rezultat favorabil în epitelizarea ulcerelor venoase.
\end{abstract}

Cuvinte cheie: plăgi cronice, ulcer venos, bacterii, antibiotic

\section{INTRODUCERE}

Plăgile se caracterizează prin deteriorarea unui ţesut, cauzată de obicei de afectarea unui organ, cel mai frecvent pielea (1). Cele trei etape ale vindecării sunt faza inflamatorie, proliferativă şi faza de remodelare. Evoluţia normală a unei plăgi trece în primele 6 zile prin faza inflamatorie caracterizată prin vasoconstricţie, coagulare, vasodilataţie, chemotaxia factorilor de coagulare, migrarea celulelor şi răspunsul celular al neutrofilelor, macrofagelor şi limfocitelor. Următoarea fază este reprezentată de faza fibroproliferativă din ziua 4 până în a treia săp- tămână, în care se formează matricea din glicozaminoglicani şi fibroblaşti, angiogeneza este stimulată de factorul endotelial de creştere şi începe procesul de epitelizare. Ultima fază este cea de maturare sau de remodelare, care începe în săptămâna a treia şi se prelungeşte de-a lungul primului an, constând în organizarea fibrelor de colagen şi înlocuirea colagenului I cu colagen III într-un raport de $4: 1(2)$.

Spre deosebire de plăgile normale, vindecarea plăgilor cronice se opreşte în faza inflamatorie şi nu progresează, din cauza anumitor factori precum

Autor corespondent:

Asist. Univ. Dr. Andra Elena Balcangiu-Stroescu, Facultatea de Medicină Dentară, Universitatea de Medicină şi Farmacie

"Carol Davila“, Bulevardul Eroilor Sanitari nr. 8, sector 5, Bucureşti, România

E-mail: stroescu_andra@yahoo.ro 
vârsta, infecţiile, ischemia, malnutriţia, diabetul, stările neoplazice etc (3).

Pielea reprezintă o gazdă pentru un număr mare de bacterii comensuale (1). Odată cu apariţia unei plăgi, bacteriile o contaminează. Plăgile sunt considerate contaminate când sunt prezente bacterii întrun număr scăzut şi colonizate când bacteriile se multiplică fără a exista o reacţie din partea gazdei. Plăgile colonizate critic sunt caracterizate prin răspunsul scăzut al gazdei, pe când cele infectate prin proliferarea bacteriană cu o reacţie crescută a gazdei ce determină afectarea tisulară. Unele plăgi se infeacteză şi un număr crescut de germeni afectează vindecarea. Infecţia unei plăgi se caracterizează printr-o cultură cantitativă de $10^{5}$ bacterii pe gram de ţesut (4). Această valoare nu este frecvent utilizată din cauza laboratoarelor puţin performante. Totodată, asocierea ischemiei, a diabetului şi a altor comorbidităţi poate scădea acest prag (4).

Plăgile cronice sunt frecvent asociate cu colonizarea bacteriană (1). Chiar dacă unele bacterii nu sunt patogene, asocierea multiplă a acestora în cazul plăgilor cronice determină o evoluţie către colonizarea critică asociată cu evoluţia lentă a vindecării (4).

Bacteriile cele mai frecvent întâlnite în plăgile cronice sunt Staphylococcus aureus, Pseudomonas aeruginosa, Enterobacter, Escherichia coli, Peptoniphilus şi Seratia (1).

Ulcerele trofice venoase sunt plăgi deschise situate între genunchi şi gleznă ce apar din cauza bolii venoase, reprezentând $80 \%$ din ulceraţiile membrului inferior (5). Aproximativ 33-60\% dintre acestea au o evoluţie mai lungă de 6 săptămâni şi sunt considerate ulcere venoase cronice (6). Unul dintre principalii factori care influenţează şi întârzie vindecarea ulcerelor este infecţia bacteriană (3).

Scopul acestei lucrări a fost de a evalua şi descrie tratamentul infecţiilor bacteriene la zece pacienţi cu ulcere venoase cronice pentru a îmbunătăţi calitatea vieţii acestora.

\section{MATERIAL ŞI METODĂ}

Am înrolat zece pacienţi cu ulceraţii cronice ale gambei cauzate de boală venoasă, pe o perioadă de

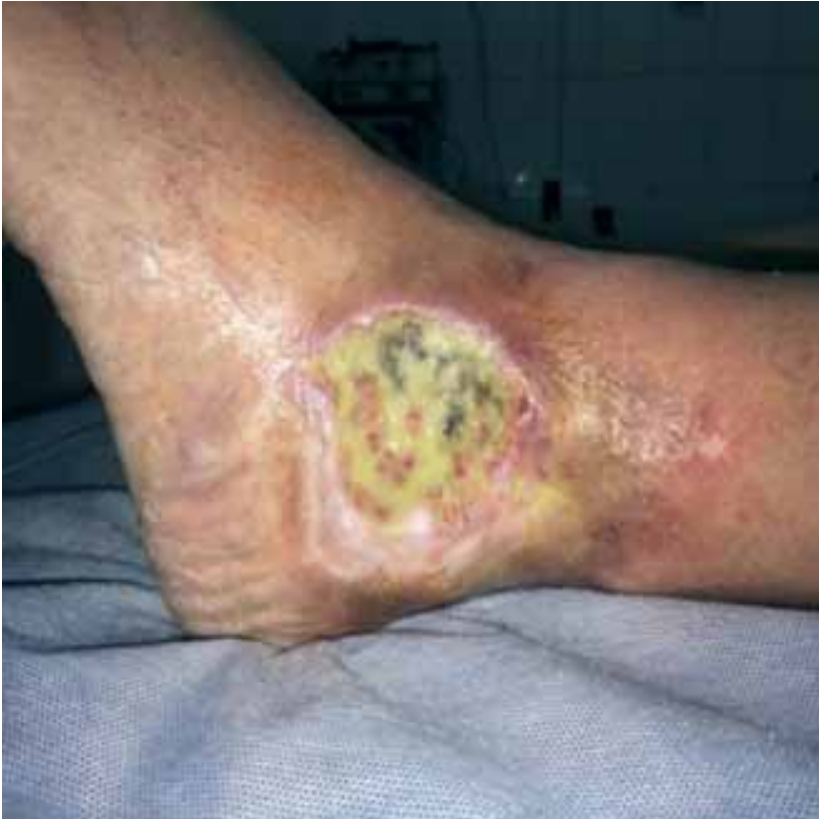

FIGURA 1. Ulcer venos cronic

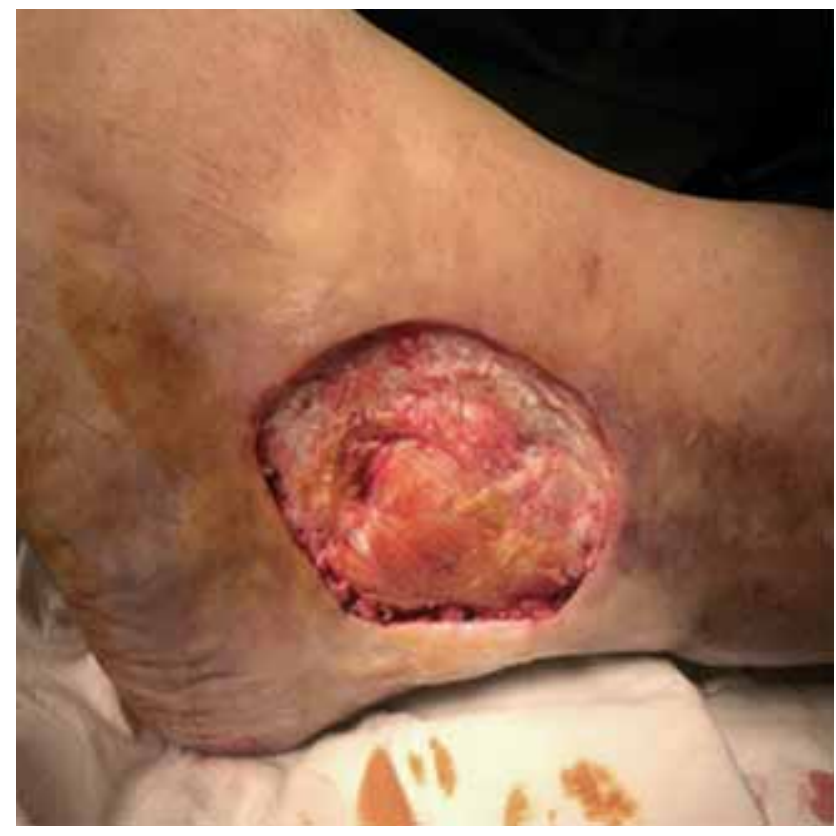

FIGURA 2. Ulcer venos după debridarea chirurgicală

6 luni. Criteriile de includere au fost definite ca ulcere de gambă de etiologie venoasă mai vechi de 6 săptămâni.

La internare, au fost recoltate analizele uzuale de sânge şi o cultură din plagă. S-a efectuat şi o evaluare nutriţională, cei mai mulţi pacienţi cu plăgi cronice suferind de malnutriţie proteică şi micronutrienţi (7). Un antibiotic de elecţie a fost administrat la pacienţii cu semne de infecţie severă precum celulită, caracterizată prin eritem, durere, 


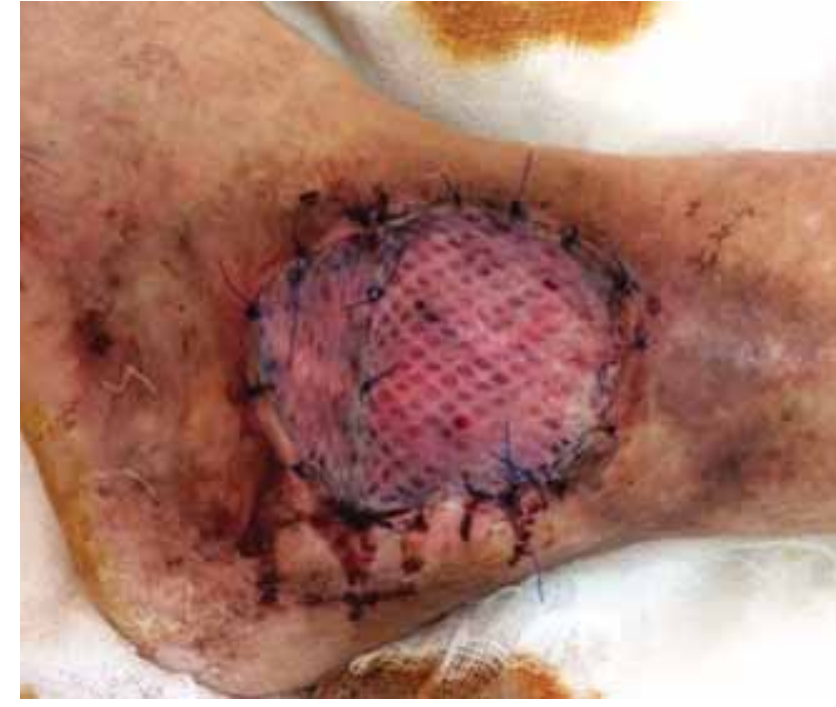

FIGURA 3. Ulcer venos acoperit cu o grefă de piele liberă despicată (a 5-a zi de la operaţie)

edem şi căldură. Restul pacienţilor au primit antibiotic după rezultatul antibiogramei.

Pansamentele au fost realizate cu sulfadiazină de argint şi un antiseptic, iar pacienţii au fost sfătuiţi să ridice extremităţile inferioare deasupra nivelului inimii, în scopul de a reduce edemul şi de a îmbunătăţi microcirculaţia şi vindecarea ulcerului.

Tratamentul chirurgical a fost instituit la pacienţii refractari la tratamentul conservator (Fig. 1). S-a realizat o debridare chirugicală cu îndepărtarea ţesutul necrotic şi a încărcăturii bacteriene (Fig. 2). După debridare şi terapia cu antibiotice, s-a recoltat o nouă cultura din plagă. În cazurile în care cultura a fost sterilă, o nouă intervenţie chirurgicală a fost programată, iar ulcerul a fost acoperit cu o grefă de piele liberă despicată (Fig. 3). Deficitele proteice şi calorice au fost suplimentate, fiind adăugaţi şi micronutrienţi.

\section{REZULTATE}

Jumătate din pacienţi au provenit din alte centre medicale, cealaltă jumătate fiind la prima internare. Tratamentul iniţial al pacienţilor proveniţi din alte centre medicale nu a avut efect.

Cel mai frecvent întâlnit germen a fost Staphylococcus aureus la şase din zece pacienţi, patru dintre aceştia fiind rezistenţi la meticilină. Pacienţii cu prima internare au avut doar un singur germen pe plagă, Staphilococcus aureus în trei cazuri şi Enterococcus faecalis şi Enterococcus Faecium. Cealaltă jumătate, constituită din pacienţii cu spitalizări anterioare au avut cel puţin doi agenţi patogeni pe plagă: Staphilococcus aureus asociat cu Klebsiella pneumonie sau cu Escherichia coli şi Pseudomonas aeruginosa; Proteus mirabilis asociat cu Escherichia coli, Pseudomonas aeruginosa cu Klebsiella oxytoca şi Morganella Morgani sau Enterecoccus faecalis cu Maltophilia Stenotrophomonas. Aceşti agenţi patogeni au avut, de asemenea, o rezistenţă crescută la antibiotice, fiind necesare antibiotice puternice pe o perioadă mai lungă de timp.

$\mathrm{Ca}$ antibiotic iniţial pentru ulcerele infectate asociate cu celulită, a fost folosită o cefalosporină de generaţia a doua, care a fost schimbată ulterior, pe baza rezultatului antibiogramei. În infecţiile cu Staphylococcus aureus, cele mai frecvente antibiotice administrate, în funcţie de rezultatul antibiogramei, au fost fluorochinolonele. În cazurile în care au fost prezenţi mai mulţi germeni, a fost administrată polimixină E asociată cu fluorochinolone (Ciprofloxacin) sau cu cefalosporine de generaţia a doua (Cefuroxim) ori cu un antibiotic din clasa glicilciclină (Tigeciclina). Perioada de timp medie de administrare de antibiotice a fost de 7 zile. După două zile de la încetarea antibioticului s-a recoltat o nouă cultură din plagă. În cazul în care această cultură a fost sterilă, pacientul a fost programat pentru o nouă intervenţie chirurgicală şi ulceraţia a fost grefată. Înainte de această a doua intervenţie chirurgicală, a fost recoltată o hemoleucogramă şi proteine totale cu scopul de a menţine o hemoglobină mai mare de $8 \mathrm{~g} / \mathrm{dl}$ şi proteine mai mari de 4,5 g/dl pentru a stimula integrarea grefei de piele. În cazul în care cultura a fost pozitivă, s-a început un nou tratament antibiotic în funcţie de noua antibiograma.

\section{DISCUTुII}

Plăgile cronice sunt predispuse la infecţii bacteriene, în special ulcerele venoase din cauza hipoxiei tisulare. Acest lucru afectează acţiunea leucocitelor asupra bacteriilor prin reducerea „stresului oxidativ“ (4). 
Bacteriile acţionează asupra plăgii în moduri diferite. Una dintre modalităţile cele mai dăunătoare este menţinerea răspunsului inflamator cu secreţia de toxine şi proteaze care distrug factorii de creştere şi împiedică vindecarea prin apariţia unui ţesut proteiform cu aspect de pseudoescară (4). O altă modalitate de afectare a vindecării este prin apariţia biofilmului, o asociere de bacterii înglobate într-o matrice. Biofilmul devine rezistent la răspunsul imun al gazdei, la acţiunea agenţilor antimicrobieni şi la antibiotice, declanşând un răspuns inflamator. Acest lucru plasează plaga într-o inflamaţie prelungită care determină secreţia de citokine şi proteaze cu degradarea ţesutului plăgii (7). În aceste cazuri, cultura plăgii prezintă limitări, deoarece mulţi germeni conţinuţi în biofilm nu pot fi izolaţi, de multe ori fiind necesară o determinare moleculară (8).

De obicei, orice întârziere în vindecarea unei plăgi ar trebui considerată de cauză infecţioasă, o cultură fiind necesară. Există, de asemenea, şi alte semne ale unei infecţii de plagă, întâlnite şi la pacienţii înrolaţi în studiu, precum durerea, edemul crescut, secreţia crescută, schimbarea aspectului şi a mirosului secreţiei (7).

De obicei, antibioticele sistemice nu sunt necesare, ci un tratament local ce permite deschiderea plăgii, debridarea şi lavajul abundent al acesteia (5). Antibioticele sunt administrate în plăgile cu o perfuzie bună şi în plăgile infectate asociate cu celulită, cu o rată scăzută de vindecare sau în care durerea s-a intensificat (1).
În studiul efectuat, antibioticul a fost ales în funcţie de statusul vascular al plăgii, numărul de leucocite şi funcţia renală a pacientului şi a fost administrat empiric până când rezultatul antibiogramei a fost gata. Alegerea s-a bazat, ca şi în alte studii, pe gradul de infecţie şi pe datele epidemiologice $(9,10)$. De obicei, infecţiile uşoare sunt determinate de coci Gram pozitivi, în special Staphilococcus aureus, în timp ce infecţiile moderate au prezenţi coci Gram pozitivi piogeni şi, în unele cazuri, de asemenea, coci Gram negativi. Plăgile cu infecţii uşoare au fost tratate iniţial $\mathrm{cu}$ un antibiotic $\mathrm{cu}$ spectru pe coci gram pozitivi comparativ cu infecţiile severe atunci când un antibiotic cu spectru larg este utilizat din cauza etiologiei polimicrobiene.

Calea de administrare corespunzătoare a fost parenterală şi a fost modificată în administrare orală atunci când pacientul s-a stabilizat.

\section{CONCLUZII}

Infecţiile au un rol important în întârzierea vindecării plăgilor cronice. Prezenţa biofimului scade activitatea antibioticelor topice sau sistemice, determinând în final un prognostic prost.

Este foarte important ca administrarea antibioticelor sistemice să se realizeze pe baza unei antibiograme şi să nu fie prelungită pe o perioadă lungă de timp. Debridarea chirurgicală este o parte importantă în tratamentul ulcerului venos, determinând scăderea încărcăturii bacteriene şi a biofilmului, potenţând astfel activitatea antibioticelor. 